\title{
Alleviatory activities in mycorrhizal tobacco plants subjected to increasing chloride in irrigation water
}

\author{
Ali Reza Safahani Langeroodi, ${ }^{1}$ Farshad Ghooshchi, ${ }^{2}$ Teena Dadgar ${ }^{3}$ \\ ${ }^{1}$ Department of Agronomy, Payame Noor University, Tehran; ${ }^{2}$ Department of Agronomy, Varamin-Pishva \\ Branch, Islamic Azad University, Varamin; ${ }^{3}$ Department of Biology, Gorgan Branch, Islamic Azad \\ University, Gorgan, Iran
}

\begin{abstract}
The effects of presence and absence of arbuscular mycorrhizal (AM+ and AM-) fungus (AMF) Glomus intraradices on agronomic and chemical characteristics of field-grown tobacco (Nicotiana tabacum L.) Virginia type (cv. K-326) plants exposed to varying concentrations of chloride $10,40,70$ and $100 \mathrm{mg} \mathrm{Cl} \mathrm{L}^{-1}$ (C1-C4) were studied over two growing seasons (2012-2013). Mycorrhizal plants had significantly higher uptake of nutrients in shoots and number of leaves regardless of intensities of chloride stress. The cured leaves yields of $\mathrm{AM}+$ plants under $\mathrm{C} 2-\mathrm{C} 4$ chloride stressed conditions were higher than AM- plants. Leaf chloride content increased in line with the increase of chloride level, while AMF colonised plants maintained low $\mathrm{Cl}$ content. $\mathrm{AM}+$ plants produced tobacco leaves that contained significantly higher quantities of nicotine than AM- plants. AM inoculation ameliorated the chloride stress to some extent. Antioxidant enzymes like superoxide dismutase, catalase, ascorbate peroxidase, and glutathione reductase as well as non-enzymatic antioxidants (ascorbic acid and glutathione) also exhibited great variation with chloride treatment. Chloride stress caused great alterations in the endogenous levels of growth hormones with abscisic acid showing increment. AMF inoculated plants maintained higher levels of growth hormones and also allayed the negative impact of chloride. The level of $40 \mathrm{mg} \mathrm{L}^{-1}$ in combination with arbuscular mycorrhizal can be con-
\end{abstract}

Correspondence: Ali Reza Safahani Langeroodi, Department of Agronomy, Payame Noor University, 19395-3697 Tehran, Iran.

Tel: +98.9113711990

E-mail: safahani_ali@yahoo.com

Acknowledgments: this study was funded by Payame Noor University, Tehran, Iran.

Key words: Glomus intraradices; Chloride; Virginia tobacco; Cured leaves yield.

Received for publication: 2 May 2016.

Revision received: 30 July 2016.

Accepted for publication: 7 August 2016.

(C) Copyright A.R. Safahani Langeroodi et al., 2017

Licensee PAGEPress, Italy

Italian Journal of Agronomy 2017; 12:792

doi:10.4081/ija.2016.792

This article is distributed under the terms of the Creative Commons Attribution Noncommercial License (by-nc 4.0) which permits any noncommercial use, distribution, and reproduction in any medium, provided the original author(s) and source are credited. sidered as the acceptable threshold to avoid adverse effects on Virginia tobacco.

\section{Introduction}

Soil salinity problems arose during the last year in coastal plains of Mediterranean areas, caused mainly by the poor quality of the irrigation water and increasing noticeably during the dry season (Selvakumar et al., 2014; Sifola and Postiglione, 2002).

Excessive quantities of chloride in the cured leaf reduce the rate of burn and cause certain adverse effects such as increased hygroscopicity, dinginess, uneven colours and undesirable odors in cured tobacco leaves (Karaivazoglou et al., 2006). Salt stress causes physiological drought to plants, imbalance in nutrient composition and excessive toxicity due to $\mathrm{Na}$ and $\mathrm{Cl}$ ions thereby leading to reduction in osmotic potential of plants, disruption of cell organelles and their metabolism. These ultimately affect plant growth and reduce the yield.

Arbuscular mycorrhizal fungi (AMF) are associated with the roots of over $80 \%$ terrestrial plant species (Smith and Read, 1997) including halophytes, hydrophytes and xerophytes. AMF have been shown to promote plant growth and salinity tolerance by many researchers; They promote salinity tolerance by employing various mechanisms, such as enhancing nutrient acquisition (Abeer et al., 2015), producing plant growth hormones, improving rhizospheric and soil conditions (Selvakumar et al., 2014), increased root hydraulic conductivity, enhanced water uptake due to extraradical hyphae, osmotic adjustment that promotes turgor maintenance and accumulation of antioxidant compounds (Colella et al., 2014) and altering the physiological and biochemical properties of the host (Gamalero et al., 2010). In addition, AMF can improve host physiological processes like water absorption capacity of plants by increasing root hydraulic conductivity and favourably adjusting the osmotic balance and composition of carbohydrates (Kumar et al., 2015; Ruiz-Lozano, 2003). This may lead to increased plant growth and subsequent dilution of toxic ion effect (Daei et al., 2009). These benefits of AMF have prompted it to be a suitable candidate for bio-amelioration of saline soils.

To date, no information is available about the interaction between of AM fungi and high chloride concentration in irrigation water on the agronomical and physiological responses of tobacco. Therefore, the purpose of this research was to determine the effect of different levels of chloride stress and AM inoculation on various morpho-biochemical parameters of tobacco. This study may be helpful in order to further understand salt tolerance mechanisms in AM plants. 


\section{Materials and methods}

\section{Field preparation and application of experimental treatments}

Field experiments were conducted in the Tirtash Tobacco Research Institute ( $3645^{\prime} \mathrm{N}$; $5344^{\prime} \mathrm{E}$, altitude: $14 \mathrm{~m}$ ) in northern Iran over two years (2012-2013). Some physicochemical characteristics of the soil used are, sand $47 \%$, silt $24.6 \%$, clay $28 \%$, lime $2.2 \%, \mathrm{pH} 7.4, \mathrm{~N} 0.13 \%$, EC $2.5 \mathrm{dS} \mathrm{m}^{-1}$, low organic carbon status $(0.40 \%)$, total $\mathrm{N}(0.06 \%)$, and available $\mathrm{P}\left(6.5 \mathrm{mg} \mathrm{kg}^{-1}\right)$ and available $\mathrm{K}$ status $\left(187.5 \mathrm{mg} \mathrm{kg}^{-1}\right)$, field capacity $26.4 \%$ dry weight and wilting point $14.9 \%$ dry weight.

The soil was kept fallow for a year to reduce indigenous mycorrhizal fungi and decompose the root fragments of previous crop to eliminate propagules. Since mycorrhizal spore propagules extracted from the native soil were extremely low (1-2 per kg), no attempt was made to fumigate the soil. Vermiculite-based mycorrhizal inoculum carrying arbuscular mycorrhizal (Glomus intraradices Schenck \& Smith; in recent years known as Rhizophagus irregularis; Schußler and Walker, 2010), which is known to colonize the roots of $N$. tabacum L. (Cosme and Wurst, 2013) fungus was applied in a tobacco nursery at a rate of $100 \mathrm{~g}$ $\mathrm{m}^{-2}$ just prior to sowing seeds on sowing lines marked at a distance of $5 \mathrm{~cm}$ apart. The inoculum was originally cultured in maize roots; heavily colonized roots $(100 \mathrm{~g})$ carrying the propagules (spores, infected roots, soil) were diluted in sterile vermiculite (1 $\mathrm{kg}$ ). The mycorrhizal and non-mycorrhizal tobacco nurseries were maintained separately. The fertility status of the nursery soil was similar to that of the experimental soil. The inoculated and noninoculated tobacco plants were irrigated once every 2-3 days. Tobacco roots were tested for mycorrhizal colonization at the end of 4 weeks after inoculation (28 days after sowing). After establishment of the symbiosis (approximately $40 \%$ root colonization), mycorrhizal and non-mycorrhizal tobacco plants were transplanted in the main field at a spacing of $0.5 \mathrm{~m}$ between plants and $1 \mathrm{~m}$ between rows, in during early June of two years (2012 and 2013). On an average, 2 plants per square meter were maintained in each plot measuring a dimension of $10 \mathrm{~m}$ length $\times 6 \mathrm{~m}$ width $\left(60 \mathrm{~m}^{2}\right)$. Also, all the experimental plots were surrounded with earth dikes, and a distance of $3 \mathrm{~m}$ between plots was left bare in order to prevent the lateral spread of water. The tillage practices, including cultivation and disking, were the common conventional practices in the region.

The plants were drip irrigated with four level of chloride included: 10, 40, 70 and $100 \mathrm{mg} \mathrm{Cl} \mathrm{L}^{-1}$ (C1-C4). Chloride was added to the water as $\mathrm{CaCl}_{2}$. The fact that the $10 \mathrm{mg} \mathrm{Cl} \mathrm{L}^{-1}$ concentration in water is considered very low and without adverse effects on tobacco (Karaivazoglou et al., 2006) led us to the decision to take this chloride concentration as control.
Before transplanting $53 \mathrm{~kg} \mathrm{ha}^{-1}$ of $\mathrm{P}$ and $125 \mathrm{~kg} \mathrm{ha}^{-1}$ of $\mathrm{K}$ were added to the top $0.2 \mathrm{~m}$ of soil. $\mathrm{N}$ fertilizers of $120 \mathrm{~kg} \mathrm{ha}^{-1}$ were distributed as follows $50 \%$ at transplanting as ammonium sulphate $(21 \% \mathrm{~N})$ and $50 \%$ as ammonium nitrate $(26 \% \mathrm{~N})$ at five side dressing. The latter was split into applications, one at seedling establishment and one at the beginning of rapid stem elongation.

During the first half of August, when approximately $50 \%$ of plants per plot were flowering, the plants were topped at a height of 24-25 leaves per plant. An average of about 64 plants per treatments was harvested from the central part of each plot $\left(32 \mathrm{~m}^{2}\right)$ to determine yield.

Rainfall and temperatures during the cultivation period (MaySeptember) in the two experimentation years are shown in Table 1. Rainfall and temperature during two years of experiments were similar and in accordance with the regional average. The same number (10) of irrigations (same amount of chloride) was applied in each year.

A $2 \times 4$ factorial randomized block design included two mycorrhizal treatments (with $\mathrm{AM}, \mathrm{AM}+$ or without $\mathrm{AM}, \mathrm{AM}-$ ) and four chloride levels in irrigation water (C1-C4) replicated four times on agronomic and chemical properties of Virginia tobacco (cv. K-326; The selected cultivar is the highest quality commercial cultivars in the north of Iran).

\section{Data collection}

\section{Photosynthesis measurement}

Carbon exchange rate (CER), transpiration rate (E) and stomatal conductance (gs) were measured by an infrared gas analyser (Li-6400; LI-COR, Lincoln, NE, USA) on four replications per treatment from 9:30 to 10:40 am at a sunny day before harvest. Measurements were recorded when the total coefficient of variation was less than $0.5 \%$.

\section{Growth measurements and biochemical analysis}

Ten plants were randomly selected from each experimental plot in each replication at flowering stage and the following parameters were recorded: dry shoot mass, dry root mass, number of leaves, percentage mycorrhizal root colonization, pigments and plant growth regulators, antioxidative enzymes and non-enzymatic. Water use efficiency (WUE), was calculated by dividing the total leaves yield $\left(\mathrm{kg} \mathrm{ha}^{-1}\right)$ by the quantity of water consumed inclusive of precipitation (mm) as indicated by Boyer (1995) and mycorrhizal dependency at each chloride level. Mycorrhizal dependency (MD) or response to mycorrhizal colonization was calculated for plants in each chloride treatment by using the following formula (Gerdemann, 1975):

$$
M D=\frac{\text { Dry weight of AM }+ \text { plant at a particular level of chloride }}{\text { Dry weight of AM }- \text { plant at the same level of salinity }} \times 100
$$

Table 1. Monthly distribution of the number of irrigations, irrigation volumes, rainfall and temperature in the two years of study.

\begin{tabular}{|c|c|c|c|c|c|c|c|c|}
\hline \multirow[t]{2}{*}{ Month } & \multicolumn{2}{|c|}{ Irrigation (n) } & \multicolumn{2}{|c|}{ Volume (mm) } & \multicolumn{2}{|c|}{ Rainfall (mm) } & \multicolumn{2}{|c|}{ Mean temperature $\left({ }^{\circ} \mathrm{C}\right)$} \\
\hline & 2012 & 2013 & 2012 & 2013 & 2012 & 2013 & 2012 & 2013 \\
\hline May & - & - & - & - & 70 & 45 & 18.1 & 18.4 \\
\hline June & 2 & 1 & 63 & 30 & 40 & 36 & 21.8 & 23.2 \\
\hline July & 5 & 5 & 138 & 170 & 25 & 15 & 25 & 26.3 \\
\hline August & 2 & 3 & 78 & 101 & 3 & 0 & 25.3 & 25.5 \\
\hline September & - & - & - & - & 42 & 40 & 20.8 & 21.5 \\
\hline
\end{tabular}

Irrigation water supplied at transplanting (average of $22 \mathrm{~mm}$ ) was not included. 
The AM fungi spore count in native field soil was minimal ( $\sim 3$ spores $100 \mathrm{~g}^{-1}$ air-dried soil). Root colonization by AM was determined by preparing root samples at $1 \mathrm{~g}$ in each experimental unit according to the method of Philips and Hayman (1970), and roots were stained using the Gridline- Intersect Method (Giovannetti and Mosse, 1980).

Each plant was extracted from the soil by digging a trench around it $0.3 \mathrm{~m}^{2}$ by $0.6 \mathrm{~m}$ deep and removing it as a block. The roots were washed well to remove all traces of soil and the plants then separated into leaves, stalks and roots. The fresh weight of the sample plant parts was recorded and the samples were then dried to a constant weight in an oven at $70^{\circ} \mathrm{C}$ whereon dry weight was then recorded.

Leaves from control and $\mathrm{Cl}$-stressed plants were excised at flowering stage to measure relative water content (RWC) and osmotic potential ( $\Psi$ s) according to Turner (1981) and MartinezBallesta et al. (2004), respectively.

\section{Extraction and quantification of pigments and plant growth regulators}

Indole acetic acid (IAA) and abscisic acid (ABA) were extracted and purified as described by Kusaba et al. (1998). The method described by Lee et al. (1998) was followed for extraction and estimation of gibberellic acid (GA3) by gas chromatograph-mass spectrometer (GC-MS). Photosynthetic pigments (chlorophyll a, chlorophyll $\mathrm{b}$ and carotenoids) in the leaves were determined as the method described by Moran (1982).

Free proline content and Electrolyte leakage (EL) in plant material were determined as the method described by (Bates et al., 1973; Dionisio-Sese and Tobita, 1998) respectively.

Extraction and estimation of antioxidative enzymes and nonenzymatic, such as ascorbate peroxidase (APX), superoxide dismutase (SOD), glutathione reductase (GR), catalase (CAT), ascorbic acid (AsA), glutathione (GSH) and oxidized glutathione
(GSSG) were measured according to Nakano and Asada (1981), Van Rossum et al. (1997), Carlberg and Mannervik (1985), Luck (1974), Law et al. (1983) and Anderson (1985), respectively.

\section{Cured leaf yield and chemical composition}

Leaf yield was determined from an average of 64 plants per plots harvested from the central part of each plot. All plants were harvested by hand, in 5 primings, by removing 4-5 leaves each time at weekly intervals starting 6 weeks after transplanting. The harvested leaves, cured in typical oven for Virginia tobacco. Yield of cured leaves was determined at standard moisture content of $19 \%$ for each of the four stalk positions.

Minerals and chemicals composition of leaf chloride content was analysed using the standard AOAC (1997) method. Total N was analysed employing the Kjeldahl procedure (Bremmer and Mulvaney, 1982). Nicotine and reducing sugars were measured using CORESTA recommended methods No. 35 (CORESTA, 1994a) and No. 38 (CORESTA, 1994b), respectively. In addition, $\mathrm{K}, \mathrm{P}$ and $\mathrm{Mg}$ were determined. $\mathrm{K}$ was determined by flame emission spectroscopy, $\mathrm{P}$ by the molybdenum blue-ascorbic acid method (Olsen and Sommers, 1982), Ca and Mg by atomic absorption spectroscopy.

\section{Statistical analysis}

Yield and other agronomic and chemical traits were subjected to analysis of variance (ANOVA). However, since the same number (10) of irrigations (same amount of chloride) was applied in each year, the response to chloride was relatively similar from year to year, as well as Bartlett's test and the combined analysis of the two growing seasons were applied. Bartlett's $\mathrm{X}^{2}$ test showed that combining the data from both years was acceptable. In the analysis that follows, all values given are the averages of the data for the 2 years combined. Means were compared using least significant difference test at $5 \%$ level.

Table 2. Mean of cured leaf yield, water use efficiency, mineral contents in leaf, number of leaves, shoot dry weight, root dry weight, percentage root colonisation, mycorrhizal dependency, nicotine, reducing sugar and proline of mycorrhizal and non-mycorrhizal tobacco plants exposed to varying concentrations of chloride (average of two growing seasons, 2012-2013).

\begin{tabular}{|c|c|c|c|c|c|c|c|c|c|c|c|}
\hline ree & $\begin{array}{c}\text { Root } \\
\text { colonisation } \\
(\%)\end{array}$ & $\begin{array}{l}\text { MD } \\
(\%)\end{array}$ & $\begin{array}{l}\text { Leaves } \\
\text { per plant }\end{array}$ & $\begin{array}{l}\text { Root dry } \\
\text { weight } \\
\text { (g plant }^{-1} \text { ) }\end{array}$ & $\begin{array}{l}\text { Shoot } \\
\text { dry weight } \\
\text { (g plant }^{-1} \text { ) }\end{array}$ & $\begin{array}{l}\text { Yield of WUE } \\
\text { Ired leaves }\left(\mathrm{kg} \mathrm{m}^{-3}\right) \\
\left(\mathrm{kg} \mathrm{ha-1)}^{-1}\right)\end{array}$ & $\begin{array}{l}\text { Mg } \\
(\%)\end{array}$ & $\begin{array}{l}\mathbf{P} \\
(\%)\end{array}$ & $\underset{(\%)}{K} \underset{(\%)}{N}$ & $\begin{array}{l}\text { Nicotine } \\
(\%)\end{array}$ & $\begin{array}{l}\text { Reducing Pr } \\
\text { sugar } \\
\text { (\%) }\end{array}$ \\
\hline
\end{tabular}

\begin{tabular}{|c|c|c|c|c|c|c|c|c|c|c|c|c|c|}
\hline \multicolumn{14}{|l|}{$\mathrm{AM}+$} \\
\hline $\mathrm{Cl}$ & $67^{\mathrm{a}}$ & $120^{a}$ & $24.2^{\mathrm{a}}$ & $29.9^{\mathrm{a}}$ & $354.5^{\mathrm{a}}$ & $2329.00^{\mathrm{a}}$ & $1.66^{\mathrm{a}}$ & $0.66^{\mathrm{a}}$ & $0.18^{a}$ & $2.2^{\mathrm{a}} 2.10$ & $1.41^{\mathrm{a}}$ & $11.1^{\mathrm{c}}$ & $2.14^{\mathrm{c}}$ \\
\hline $\mathrm{C} 2$ & $59^{\mathrm{b}}$ & $119^{a}$ & $23^{\mathrm{ab}}$ & $25.8^{\mathrm{b}}$ & $327.4^{\mathrm{ab}}$ & $2297.66^{\mathrm{a}}$ & $1.64^{\mathrm{a}}$ & $0.64^{\mathrm{a}}$ & $0.17^{\mathrm{ab}}$ & $2.1^{\mathrm{ab}} 2.09$ & $1.23^{\mathrm{ab}}$ & $12.5^{\mathrm{bc}}$ & $3.76^{\mathrm{b}}$ \\
\hline $\mathrm{C} 3$ & $50^{c}$ & $115^{b}$ & $21^{\mathrm{b}}$ & $24.1^{\mathrm{bc}}$ & $295.1^{\mathrm{bc}}$ & $2021.56^{\mathrm{b}}$ & $1.57^{\mathrm{ab}}$ & $0.60^{\mathrm{b}}$ & $0.16^{\mathrm{b}}$ & $2.0^{\mathrm{b}} \quad 2.05$ & $1.2^{\mathrm{b}}$ & $13.3^{\mathrm{b}}$ & $4.89^{b}$ \\
\hline $\mathrm{C} 4$ & $43.3^{\mathrm{d}}$ & $113^{b}$ & $18.5^{c}$ & $23.2^{c}$ & $290.2^{c}$ & $1971.02^{\mathrm{b}}$ & $1.40^{\mathrm{b}}$ & $0.59^{\mathrm{b}}$ & $0.14^{c}$ & $1.8^{\mathrm{c}} 2.01$ & $1.15^{b}$ & $15.7^{\mathrm{a}}$ & $6.18^{\mathrm{a}}$ \\
\hline LNSD & 6.1 & 3 & 2.2 & 1.8 & 35.2 & 66.3 & 0.19 & 0.03 & 0.02 & 0.2 ns & 0.19 & 1.5 & 1.16 \\
\hline \multicolumn{14}{|l|}{ AM- } \\
\hline $\mathrm{Cl}$ & - & - & $21^{\mathrm{a}}$ & $25.5^{\mathrm{a}}$ & $295.4^{\mathrm{a}}$ & $1998.21^{\mathrm{a}}$ & $1.44^{\mathrm{a}}$ & $0.61^{\mathrm{a}}$ & $0.12^{\mathrm{a}}$ & $1.6^{\mathrm{a}} 2.00^{\mathrm{a}}$ & 1.09 & $8.1^{\mathrm{b}}$ & $1.73^{b}$ \\
\hline $\mathrm{C} 2$ & - & - & $16.2^{\mathrm{b}}$ & $21.7^{\mathrm{b}}$ & $278.7^{a b}$ & $1899.32^{b}$ & $1.35^{\mathrm{a}}$ & $0.54^{\mathrm{b}}$ & $0.11^{\mathrm{a}}$ & $1.5^{\mathrm{a}} 1.90^{\mathrm{ab}}$ & 1.03 & $10.2^{\mathrm{a}}$ & $2.80^{\mathrm{ab}}$ \\
\hline C3 & - & - & $12^{c}$ & 19.1 $1^{\mathrm{bc}}$ & $256.8^{\mathrm{bc}}$ & $1785.74^{c}$ & $1.23^{b}$ & $0.51^{b c}$ & $0.09^{b}$ & $1.3^{\mathrm{b}} 1.85^{\mathrm{b}}$ & 1.08 & $10.9^{\mathrm{a}}$ & $3.23^{\mathrm{a}}$ \\
\hline C4 & - & - & $11^{c}$ & $18.2^{c}$ & $244.5^{\mathrm{c}}$ & $1734.11^{c}$ & $1.20^{\mathrm{b}}$ & $0.49^{c}$ & $0.08^{b}$ & $1.2^{\mathrm{b}} 1.80^{\mathrm{b}}$ & 1.1 & $11.3^{\mathrm{a}}$ & $3.45^{\mathrm{a}}$ \\
\hline LSD & & & 3.7 & 2.8 & 30.5 & 80.7 & 0.11 & 0.04 & 0.02 & $0.2 \quad 0.17$ & ns & 1.8 & 1.27 \\
\hline \multicolumn{14}{|l|}{ ANOVA } \\
\hline $\mathrm{C}$ & $*$ & $*$ & $*$ & $*$ & $*$ & $*$ & $*$ & ns & ns & ns ns & ns & $*$ & * \\
\hline $\mathrm{AM}$ & $* *$ & $* *$ & $* *$ & $* *$ & $* *$ & $* *$ & $* *$ & $*$ & $*$ & $* \quad *$ & * & * & $*$ \\
\hline $\mathrm{C} \times \mathrm{AM}$ & $*$ & $*$ & $*$ & $*$ & $*$ & $*$ & $*$ & $*$ & $*$ & $* \quad *$ & $*$ & $*$ & $*$ \\
\hline
\end{tabular}

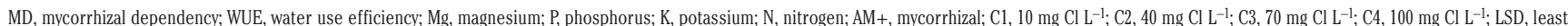
significance difference; AM-, non-mycorrhizal; ANOVA, analysis of variance; $\mathrm{C}$, chloride; AM, arbuscular mycorrhizal. ns, not significant; ${ }^{*} \mathrm{P} \leq 0.05 ;{ }^{* *} \mathrm{P} \leq 0.01$. ${ }^{\mathrm{a}-\mathrm{d}} \mathrm{Means}$ with different letters are significantly different at $\mathrm{P} \leq 0.05$. 


\section{Results and discussion}

\section{Mycorrhizal colonisation and mycorrhizal dependency}

Twenty eight day old mycorrhiza-inoculated tobacco seedlings had $40 \%$ colonisation at the time of transplanting while non-inoculated seedlings registered only $1-2 \%$ colonisation. After a month of exposure to varying concentrations of chloride level in the main field, none of the tobacco plants in the non-inoculated treatments were colonised by the AM when examined during the experimentation (Table 2). The highest AM root colonisation was observed in $\mathrm{C} 1$ treatment, and it decreased significantly with increasing chloride levels (Table 2). Previous research has shown that salinity, not only affects negatively the host plant but also the AMF. It can hamper colonisation capacity, spore germination, and growth of fungal hyphae and hyphal spreading after initial colonisation (Kumar et al. 2010, 2015; Miransari, 2010).

The data presented in Table 2 reveal that the mycorrhizal dependency (MD) of tobacco plants were significantly reduced by increased chloride levels (Table 2). In AM tobacco, the highest MD values belonged to $\mathrm{C}$ lin comparison with other chloride levels. A decrease in $\mathrm{MD}$ at higher chloride level (C2-C4) could be due to the inhibitory effect of chloride on AM fungal growth and spore density (Kumar et al., 2015).

\section{Plant growth parameters}

The treatments of increasing chloride level significantly decreased all the growth attributes such as number of leaves, dry shoot mass and dry root mass of both AM- and AM+ tobacco plants (Table 2). However, in growth parameters, AM+ plants were higher than AM- plants regardless of concentrations of chloride level. The highest chloride level, AM+ plants were comparable to C1, AM- plants.

In Vigna unguiculata L, Abeer et al. (2015) demonstrated that length as well as fresh and dry biomass of shoot and root declined with the increasing salinity. Exposure to stress reduces hydraulic conductivity and disturbs extension of cell wall causing considerable decline in morphological attributes of plants (Selvakumar et al., 2014). An increased root length and density or an altered root system morphology, as enhancing soil exploration and water extraction, have been hypothesised as potential mechanisms for the improved stress resistance of mycorrhized plants (Gamalero et al., 2010; Candido et al., 2013, 2015).

\section{Cured leaf yield and water use efficiency}

The cured leaf yield and water use efficiency (WUE) of tobacco decreased significantly under increasing concentrations of chloride. Conversely, mycorrhizal inoculation enhanced the tobacco leaf production and WUE regardless of concentrations of chloride level (Table 2). Mycorrhizal colonisation improved growth, water status, nutrient content, yield and quality of tobacco leaf when exposed to varying concentrations of chloride level. The 2-year field study suggests that AM inoculation improves salinity tolerance of tobacco plants as a secondary consequence of enhanced nutritional status of the host plant, especially $\mathrm{N}$ and $\mathrm{P}$.

Tobacco leaf yield decreased with salinity, in agreement with many studies on tobacco (Karaivazoglou et al., 2005; Sifola and Postiglione, 2002). Reduced yield under chloride stress treatments could be attributed to $\mathrm{CaCl}_{2}$ increasing the osmotic potential of the solution and the activity of $\mathrm{Cl}$ in the root zone (Karaivazoglou et al., 2005, 2006). Those changes may have affected plant growth and, consequently, yield through their effects on plant-water rela- tionship and on nutritional imbalances (Abeer et al., 2015). Direct effects of salinity include accumulation of salt in old leaves, which may hasten leaf death. This prevents the supply of assimilates or hormones to the growing regions which eventually affects the plant growth. The improved nutritional status and relative water content caused by mycorrhizal colonisation would have alleviated salinity impacts and promoted tobacco leaf production under varying concentrations of chloride. Because mycorrhizal treatments consistently increased leaf yields under varying concentrations of chloride, WUE of AM plants were much higher than control plants.

In this study, mycorrhizal tobacco plants had higher WUE values compared with non-mycorrhizal plants, as indicated by lower water loss and higher RWC, probably because of improvement of water absorption capacity by AM fungus.

Our results also confirmed the water status (WUE and RWC) of tobacco plants positively correlated with photosynthesis activity. Mycorrhizal plants showed higher levels of photosynthesis activity indicating that AM symbiosis had a positive impact on mass flow of water to the leaf surface, and an increased water absorption by extraradical hyphae (Zhu et al., 2011). On the other hand, AM inoculated plants had better water status, which allow host plants to sustain higher stomatal conductance and transpiration rate (Table 3 ), consequently reducing leaf epidermal resistance and improving photosynthetic activity.

\section{Leaf mineral composition}

The effect of chloride on the content of $\mathrm{K}, \mathrm{N}, \mathrm{Mg}$ and $\mathrm{P}$ was not significant, although a slight decreasing trend was recorded with the increase of chloride in irrigation water (Table 2). Colonisation of AMF caused increase in these mineral ions as compared to control non-AMF plants and also reduced the chloride stress induced impact to marked extent (Table 2). It is well known that salinity causes nutrient imbalance in plants. AMF help plants to uptake more nutrient. Chloride ion has antagonistic relationship with several other ions like K. In present study higher concentration of chloride and lowered concentrations of other ions like K, P, $\mathrm{Mg}$ under increasing of concentrations of chloride is in concurrence with the findings of Bilgili et al. (2011) for canola and Abeer et al. (2015) for cowpea. AMF not only reduced the deleterious effect of excess chloride by reducing its uptake but also caused a significant increase in uptake of other important mineral elements like $\mathrm{K}, \mathrm{P}$ and $\mathrm{Mg}$. AMF colonisation in wheat significantly increased the shoot concentrations of $\mathrm{P}, \mathrm{K}$, and $\mathrm{Zn}$ whereas decreased $\mathrm{Na}$ and $\mathrm{Cl}$ concentrations (Daei et al., 2009).

Regression analysis between levels of chloride in irrigation water and chloride concentrations in the leaves showed that chloride concentrations in leaves had a linear response to rates of irrigation water chloride (Figure 1), the rate of linear increase of leaf chloride concentration was higher in AM-plants than AM+ plants. Chloride concentration in leaves can be predicted with the equations are shown in Figure 1, according to chloride level in irrigation water and arbuscular mycorrhizal inoculation. It is considered that an acceptable Virginia tobacco should contain less than 1\% of chloride. Leaves with higher chloride concentration are of poor quality with reduced burning rate (Sifola and Postiglione, 2002). Based on the above results it is preferable to use irrigation water with chloride concentration below $25 \mathrm{mg} \mathrm{L}^{-1}$ since at this level the chloride concentration in the leaves remained around $1 \%$. On the other hand, the chloride level of $40 \mathrm{mg} \mathrm{L}^{-1}$ in irrigation water in combination with AMF can be considered as the threshold upper limit. In such high concentrations the use of AMF are recommended, because keep the leaf chloride concentrations around the acceptable level (Figure 1). 


\section{Nicotine and reducing sugar}

In the present study, reducing sugar content was significantly enhanced with an increase in chloride level from $\mathrm{C} 1$ to $\mathrm{C} 4$, regardless of mycorrhizal treatments (Table 2). AM+ plants had considerably higher amount of reducing sugar compared to AM- plants (Table 2). Increasing chloride level enhanced soluble carbohydrate concentration in tobacco regardless of mycorrhizal treatments and is mainly because, carbohydrate plays a crucial role in maintaining osmotic balance in plant exposes to salt stress and hence protects plant from adverse salt effect (Datta and Kulkarin, 2014). Under increasing chloride level, AMF colonisations in tobacco increased reducing sugar accumulation, which is required for better osmoprotection [this kind of data is supported by Datta and Kulkarni (2014)].

The effect of chloride on nicotine concentration of leaves was not significant and showed inconsistent trend (Table 2). The nicotine concentration in the leaves of the tobacco was enhanced by AMF regardless of the chloride levels (Table 2). Similar inconsistent results and a very slight effect of chloride on nicotine content in Virginia, Burley, and Maryland tobacco have been reported by others (Collins and Hawks, 1993).

In our study the direction of microbial effects on nicotine concentrations in the leaves was often associated with the direction of their effects on $\mathrm{N}$ concentration, and independent of leaves yield. AMF is known to incorporate inorganic $\mathrm{N}$ outside the roots into amino acids, and translocate it from the extraradical to the intraradical mycelium as arginine (Cosme and Wurst, 2013), which is a precursor of nicotine (Fritz et al., 2006). This may be the reason why in our set up the positive effects of AMF on leaves $\mathrm{N}$ concentration were associated with the greatest increases in nicotine.

\section{Photosynthetic activity, chlorophyll contents and carotenoids}

Increasing of concentrations of chloride in irrigation water markedly decreased their carbon exchange rate (CER) and $\mathrm{E}$ in the
AM- plants (Table 4). Chloride stress decreased their $g_{s}$ in all plants. Mycorrhizal plants had higher CER, E and gs than the AMplants under all concentrations of chloride level (Table 4).

Significant reduction in photosynthesis was found in saltstressed tobacco (Sifola and Postiglione, 2002). In the present study, Increasing of concentrations of chloride also reduced the $\mathrm{CER}, \mathrm{E}$ and gs in both AM- and AM+ plants. However, mycorrhizal plants had significantly higher CER, E and gs than the nonmycorrhizal plants under varying concentrations of chloride level (Table 4). A number of studies have demonstrated that, during abiotic stress, mycorrhizal plants often maintain higher gas exchange rates than non-mycorrhizal plants (Ruiz-Lozano, 2003). These positive effects may also have accounted for the enhanced plant growth of AM-colonised plants, most probably by enhancing $\mathrm{CO}_{2}$ fixation under salt stress. The higher values of photosynthetic

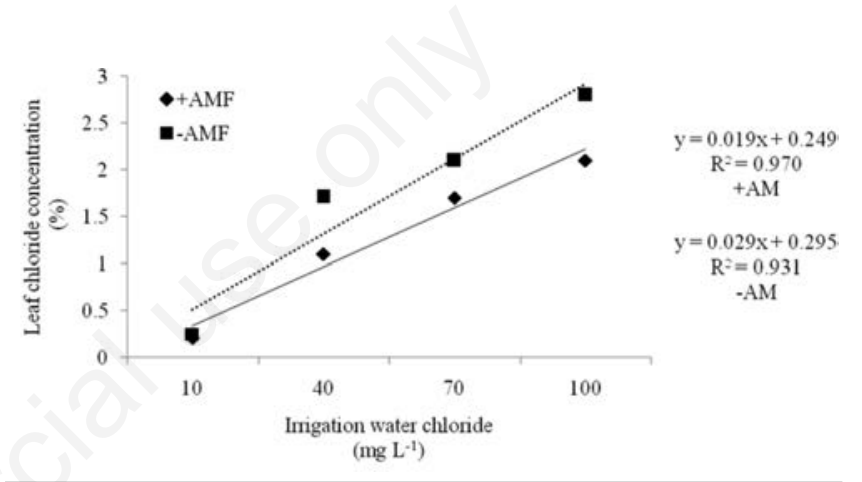

Figure 1. Correlation between levels of irrigation water chloride and chloride concentrations of leaves in presence and absence of arbuscular mycorrhizal fungi (average of two growing seasons, 2012-2013).

Table 3. Mean of catalase, ascorbate peroxidase, superoxide dismutase, ascorbic acid, reduced glutathione, oxidised glutathione, and glutathione reductase in leaf of mycorrhizal and non-mycorrhizal tobacco plants exposed to varying concentrations of chloride (average of two growing seasons, 2012-2013).

\begin{tabular}{|c|c|c|c|c|c|c|c|}
\hline Treatment & $\begin{array}{c}\text { SOD } \\
\text { (EU mg-1 } \\
\text { protein) }\end{array}$ & $\begin{array}{c}\text { CAT } \\
\text { (EU mg-1 } \\
\text { protein) }\end{array}$ & $\begin{array}{c}\text { APX } \\
\text { (EU mg-1 } \\
\text { protein) }\end{array}$ & $\begin{array}{c}\text { GR } \\
\text { EU mg-1 } \\
\text { (protein) }\end{array}$ & $\begin{array}{c}\text { ASA } \\
(\mathrm{n} \mathrm{Molg} \\
\left.\text { fresh } \mathrm{wt}^{-1}\right)\end{array}$ & $\begin{array}{c}\text { GSH } \\
(\mathrm{n} \mathrm{Mol} \mathrm{g} \\
\left.\text { fresh } \mathrm{wt}^{-1}\right)\end{array}$ & $\begin{array}{c}\text { GSSG } \\
\text { (n Mol g } \\
\left.\text { fresh wt }{ }^{-1}\right)\end{array}$ \\
\hline \multicolumn{8}{|l|}{$\mathrm{AM}+$} \\
\hline $\mathrm{Cl}$ & $115^{c}$ & $125^{\mathrm{d}}$ & $4.5^{\mathrm{c}}$ & $8.1^{\mathrm{c}}$ & $5.5^{\mathrm{a}}$ & $97.2^{\mathrm{c}}$ & $25.7^{c}$ \\
\hline $\mathrm{C} 2$ & $136^{\mathrm{b}}$ & $147^{c}$ & $6.7^{\mathrm{b}}$ & $9.1^{\mathrm{c}}$ & $4.7^{\mathrm{b}}$ & $153.1^{\mathrm{b}}$ & $55.2^{\mathrm{b}}$ \\
\hline C3 & $140^{\mathrm{ab}}$ & $175^{b}$ & $8.1^{\mathrm{a}}$ & $13.0^{\mathrm{b}}$ & $4.3^{\mathrm{b}}$ & $174.5^{\mathrm{ab}}$ & $64.2^{\mathrm{b}}$ \\
\hline $\mathrm{C} 4$ & $149^{a}$ & $195^{\mathrm{a}}$ & $8.9^{\mathrm{a}}$ & $14.2^{\mathrm{a}}$ & $4.1^{\mathrm{b}}$ & $201.7^{\mathrm{a}}$ & $87.5^{\mathrm{a}}$ \\
\hline LSD & 10 & 15 & 1.2 & 1.1 & 0.7 & 37.1 & 21.2 \\
\hline \multicolumn{8}{|l|}{ AM- } \\
\hline $\mathrm{Cl}$ & $95^{\mathrm{c}}$ & $101^{\mathrm{c}}$ & $4.1^{\mathrm{c}}$ & $7.1^{\mathrm{b}}$ & $4.8^{\mathrm{a}}$ & $87.7^{c}$ & $28.2^{c}$ \\
\hline $\mathrm{C} 2$ & $120^{\mathrm{b}}$ & $133^{b}$ & $6.2^{\mathrm{b}}$ & $8.5^{b}$ & $3.1^{\mathrm{b}}$ & $145.1^{\mathrm{b}}$ & $44.8^{\mathrm{bc}}$ \\
\hline C3 & $133^{\mathrm{a}}$ & $154^{\mathrm{a}}$ & $7.1^{\mathrm{ab}}$ & $10.3^{\mathrm{a}}$ & $2.8^{\mathrm{b}}$ & $165.1^{\mathrm{ab}}$ & $59.4^{\mathrm{b}}$ \\
\hline C4 & $141^{\mathrm{a}}$ & $160^{\mathrm{a}}$ & $7.7^{\mathrm{a}}$ & $11.2^{\mathrm{a}}$ & $2.7^{\mathrm{b}}$ & $189.9^{\mathrm{a}}$ & $78.5^{\mathrm{a}}$ \\
\hline LSD & 11 & 17 & 1.4 & 1.5 & 0.9 & 38.3 & 25.1 \\
\hline \multicolumn{8}{|l|}{ ANOVA } \\
\hline C & * & * & * & $*$ & $*$ & * & $*$ \\
\hline AM & $*$ & $*$ & $*$ & $*$ & * & $*$ & $*$ \\
\hline $\mathrm{C} \times \mathrm{AM}$ & $* *$ & $* *$ & $* *$ & $* *$ & * & $*$ & * \\
\hline
\end{tabular}

$\mathrm{SOD}$, superoxide dismutase; EU, endotoxin units; CAT, catalase; $\mathrm{APX}$, ascorbate peroxidase; $\mathrm{GR}$; glutathione reductase; $\mathrm{ASA}$, ascorbic acid; $\mathrm{GSH}$, reduced glutathione; $\mathrm{AM}+$, mycorrhizal; $\mathrm{Cl}, 10 \mathrm{mg} \mathrm{Cl} \mathrm{L}^{-1}$; $\mathrm{C} 2,40 \mathrm{mg} \mathrm{Cl}$ $\mathrm{L}^{-1}$; $\mathrm{C} 3,70 \mathrm{mg} \mathrm{Cl} \mathrm{L}{ }^{-1}$; $\mathrm{C} 4,100 \mathrm{mg} \mathrm{Cl} \mathrm{L}^{-1}$; LSD, least significance difference; AM-, non-mycorrhizal; ANOVA, analysis of variance; C, chloride; AM, arbuscular mycorrhizal. *P $\leq 0.05$; **P $\leq 0.01$. ${ }^{\mathrm{a}-\mathrm{d}} \mathrm{Means}$ with different letters are significantly different at $\mathrm{P} \leq 0.05$. 
activity in mycorrhizal plants indicate that the photosynthetic apparatus of these plants is less damaged by the salt stress imposed (Aroca et al., 2013).

AM symbiosis enhanced the concentrations of chlorophyll a, chlorophyll $\mathrm{b}$ and carotenoid in all concentrations of chloride level (Table 4). The stress of increasing concentrations of chloride significantly decreased the concentrations of chlorophyll $a, b$ and carotenoid (Table 4). Reduction in chlorophyll contents due to increasing of chloride level is in line with the findings of Karaivazoglou et al. (2005), Kumar et al. (2015), and Abeer et al. (2015), who have reported a considerable decline in chlorophyll contents of Nicotiana tabacum; Jatropha curcas and Vigna unguiculata plants exposed to salinity stress. AMF inoculation increases chlorophyll content because of its direct influence on the uptake of $\mathrm{Mg}$, which is an important component of chlorophyll pigment (Abeer et al., 2015).

\section{Membrane stability index and proline content}

Electrolyte leakage from the cellular membranes of tobacco plants increased considerably under increasing of chloride level (Table 4). However, application of AMF checked the electrolyte leakage significantly in the AM-inoculated plants exposed to chloride stress (Table 4). Proline accumulation increased in AMF inoculated as well as chloride stressed plants as compared to control (Table 2). However increase was more conspicuous under chloride stressed plants. Inoculation of AMF in chloride stressed plants further enhanced the accumulation of proline (Table 2). More decrease of electrolyte leakage in AM-colonised tobacco than in non-AMF ones seem to be related to a high accumulation of proline in shoot of the plants. proline may act as osmolyte and stabilising protein.

Membrane permeability usually appraised as electrolyte leakage is a key indicator of membrane integrity in plants subjected to stress conditions (Datta and Kulkarni, 2014). Mycorrhizal colonisations in plants lowered electrolyte leakage concentration in tobacco plants. Hence it can be suggested that, mycorrhizal associations in tobacco helped to improve membrane structure and its stability under chloride stress condition. Similar type of finding was observed when mycorrhizal Acacia Arabica and Lycopersicon esculentum plants were allowed to grow under saline condition and had less membrane permeability over non-mycorrhizal plants (Datta and Kulkarni, 2014; He et al., 2007).

In many plants, various solutes such as proline have been shown to accumulate during salinity. Their accumulation might be of importance by regulating cytosolic $\mathrm{pH}$ and NDA/NDAH rate, stabilising proteins and scavenging hydroxyl radicals protecting cells from the adverse effect of ROS (Abeer et al., 2015). Similar results were reported by Kumar et al. (2015), who postulated that the proline level increases in the stressed AM- Jatropha curcas plants.

\section{Osmotic potential and relative water content}

The leaf relative water content (RWC) and osmotic potential of AM+ and AM- tobacco plants altered significantly (Table 4). The RWC decreased progressively with increasing concentrations of chloride level and consequently, osmotic potential also decreased in order to maintain turgor potential values, which were even increased with concentrations of chloride (Table 4). However, chloride stressed AM+ tobacco plants maintained higher RWC regardless of concentrations of chloride in irrigation water and were comparable to $\mathrm{C} 1 \mathrm{AM}-$ plants. Mycorrhizal inoculation increased osmotic potential and consequently decreased turgor potential for $\mathrm{AM}+$ tobacco plants.

Improved water uptake as a result of AMF is possibly due to the direct influence of AMF hyphae on the root morphology and the improved $\mathrm{N}$ and $\mathrm{P}$ nutritional status (Wu et al., 2014). The $\mathrm{P}$ content of mycorrhizal tobacco plants was consistently higher than non-mycorrhizal plants regardless of intensities of chloride stress. A close relationship between $\mathrm{P}$ content and salt tolerance has been reported earlier (Selvakumar et al., 2014).

Table 4. Mean of chlorophyll a, chlorophyll b, carbon exchange rate, stomatal conductance, transpiration rate, relative water content, membrane stability index, osmotic potential, and carotenoids in leaf of mycorrhizal and non-mycorrhizal tobacco plants exposed to varying concentrations of chloride (average of two growing seasons, 2012-2013).

\begin{tabular}{|c|c|c|c|c|c|c|c|c|c|}
\hline Treatment & $\begin{array}{c}\text { CER } \\
\left(\mu \mathrm{mol} \mathrm{\textrm {m } ^ { - 2 }}\right. \\
\left.\mathrm{s}^{-1}\right)\end{array}$ & $\left(\mathrm{cm} \mathrm{s}^{-1}\right)$ & $\begin{array}{c}\mathrm{E} \\
\left(\mathrm{mmol} \mathrm{H} \mathrm{H}_{2} \mathrm{O}\right. \\
\left.\mathrm{m}^{-2} \mathrm{~s}^{-1}\right)\end{array}$ & $\begin{array}{l}\text { Chlorophyll a } \\
(\mathrm{mg} g \\
\left.\text { fresh } \mathrm{wt}^{-1}\right)\end{array}$ & $\begin{array}{l}\text { Chlorophyll b } \\
\text { (mg g } \\
\left.\text { fresh wt } \mathrm{wt}^{-1}\right)\end{array}$ & $\begin{array}{l}\text { Carotenoids } \\
(\mathrm{mg} \mathbf{g} \\
\left.\text { fresh } \mathrm{wt}^{-1}\right)\end{array}$ & $\begin{array}{l}\text { RWC } \\
(\%)\end{array}$ & $\begin{array}{c}\text { MSI } \\
(\%)\end{array}$ & $\begin{array}{c}\Psi_{\mathrm{s}} \\
(\mathrm{MPa})\end{array}$ \\
\hline \multicolumn{10}{|l|}{$\mathrm{AM}+$} \\
\hline $\mathrm{Cl}$ & $8.4^{\mathrm{a}}$ & $1.90^{\mathrm{a}}$ & $11.5^{\mathrm{a}}$ & $1.251^{\mathrm{a}}$ & $0.340^{\mathrm{a}}$ & $0.188^{a}$ & $96.82^{\mathrm{a}}$ & $93.71^{\mathrm{a}}$ & -1.33 \\
\hline $\mathrm{C} 2$ & $7.9^{\mathrm{a}}$ & $1.81^{\mathrm{ab}}$ & $10 . g^{\mathrm{ab}}$ & $1.107^{b}$ & $0.324^{\mathrm{ab}}$ & $0.164^{b}$ & $89.74^{\mathrm{ab}}$ & $88.25^{\mathrm{a}}$ & -1.45 \\
\hline C3 & $6.4^{\mathrm{b}}$ & $1.76^{\mathrm{bc}}$ & $10.1^{\mathrm{b}}$ & $0.987^{\mathrm{bc}}$ & $0.309^{b}$ & $0.140^{c}$ & $83.01^{b c}$ & $73.17^{\mathrm{b}}$ & -1.65 \\
\hline $\mathrm{C} 4$ & $5.9^{\mathrm{b}}$ & $1.65^{c}$ & $9.4^{\mathrm{b}}$ & $0.850^{c}$ & $0.285^{c}$ & $0.114^{\mathrm{d}}$ & $78.85^{\mathrm{c}}$ & $71.12^{\mathrm{b}}$ & -1.85 \\
\hline LSD & 0.7 & 0.13 & 1.1 & 0.14 & 0.017 & 0.021 & 9.1 & 8.5 & ns \\
\hline \multicolumn{10}{|l|}{ AM- } \\
\hline $\mathrm{Cl}$ & $6.3^{\mathrm{a}}$ & $1.69^{\mathrm{a}}$ & $8.7^{\mathrm{a}}$ & $0.997^{\mathrm{a}}$ & $0.286^{\mathrm{a}}$ & $0.138^{a}$ & $90.12^{\mathrm{a}}$ & $87.12^{\mathrm{a}}$ & $-1.43^{\mathrm{a}}$ \\
\hline $\mathrm{C} 2$ & $5.0^{\mathrm{b}}$ & $1.48^{\mathrm{b}}$ & $8.07^{a b}$ & $0.77^{\mathrm{b}}$ & $0.271^{\mathrm{a}}$ & $0.125^{\mathrm{a}}$ & $83.10^{\mathrm{ab}}$ & $68.58^{\mathrm{bc}}$ & $-2.55^{b}$ \\
\hline C3 & $4.8^{\mathrm{b}}$ & $1.37^{\mathrm{b}}$ & $7.21^{b c}$ & $0.514^{c}$ & $0.204^{\mathrm{b}}$ & $0.098^{b}$ & $74.85^{b}$ & $57.12^{\mathrm{cd}}$ & $-2.63^{b}$ \\
\hline $\mathrm{C} 4$ & $4.1^{\mathrm{b}}$ & $1.2^{\mathrm{c}}$ & $6.3^{c}$ & $0.451^{\mathrm{c}}$ & $0.174^{c}$ & $0.045^{c}$ & $69.5^{\mathrm{b}}$ & $49.32^{\mathrm{d}}$ & $-2.9^{b}$ \\
\hline LSD & 1.1 & 0.16 & 1.3 & 0.22 & 0.013 & 0.023 & 8.3 & 15 & 1.1 \\
\hline \multicolumn{10}{|l|}{ ANOVA } \\
\hline C & $*$ & $*$ & $*$ & $*$ & $*$ & $*$ & $*$ & $*$ & $*$ \\
\hline $\mathrm{AM}$ & $*$ & $*$ & $*$ & $*$ & $*$ & $*$ & $*$ & $*$ & $*$ \\
\hline $\mathrm{C} \times \mathrm{Al}$ & 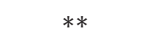 & $*$ & $*$ & $*$ & * & $*$ & $*$ & $*$ & $*$ \\
\hline
\end{tabular}

CER, carbon exchange rate; $\mathrm{g}_{\mathrm{s}}$, stomatal conductance; $\mathrm{E}$, transpiration rate; $\mathrm{RWC}$, relative water content; $\mathrm{MSI}$, membrane stability index; $\Psi_{\mathrm{S}}$, osmotic potential; $\mathrm{AM}+$, mycorrhizal; $\mathrm{Cl}, 10 \mathrm{mg} \mathrm{Cl}_{\mathrm{L}}^{-1}$; $\mathrm{C}_{2}, 40 \mathrm{mg} \mathrm{Cl}^{-1}$; $\mathrm{C}$, $70 \mathrm{mg} \mathrm{Cl} \mathrm{L}^{-1} ; \mathrm{C} 4,100 \mathrm{mg} \mathrm{Cl} \mathrm{L}^{-1}$; LSD, least significance difference; AM-, non-mycorrhizal; ANOVA, analysis of variance; C, chloride; AM, arbuscular mycorrhizal. *P $\leq 0.05$; **P $\leq 0.01$. a-dMeans with different letters are significantly different at $\mathrm{P} \leq 0.05$. 


\section{Antioxidant enzymes and non-enzymatic activities}

Results regarding activities of antioxidant enzymes are depicted in Table 3. Chloride stress caused a significant increase in activities of antioxidant enzymes studied and increase was consistent with the increase in concentration of chloride (Table 3). AMF alone increased the activities of SOD, CAT, GR and APX (Table 3 ). In combination with chloride treatment AMF inoculation further enhanced the activities of antioxidant enzymes studied.

Results pertaining to the combined effect of chloride and AMF on ASA, GSSG and GSH are depicted in Table 3. Increasing concentrations of chloride level reduced ASA content while as GSSG and GSH was increased. However inoculation of AMF caused considerable increase in these attributes (Table 3). AMF inoculation in chloride stressed plants further enhanced the contents of GSSG and GSH (Table 3).

Antioxidant enzymes play an important role in scavenging of reactive oxygen species and hence averting the oxidative stress induced damaging effects on several sensitive molecules like proteins nucleic acids and lipids. In our results increase in activities of SOD, CAT, GR and APX due to chloride stress is in concurrence with the findings of Abd_Allh et al. (2015) for Sesbania sesban. SOD is involved in scavenging of superoxide radicals into water and hydrogen peroxide (Mittler, 2002). $\mathrm{H}_{2} \mathrm{O}_{2}$ produced is converted into water and oxygen either by CAT and APX (Mittler, 2002). Increased activities of antioxidant enzymes in AMF plants support the findings of Abd_Allh et al. (2015) for Sesbania sesban and Latef and Chaoxing (2011) for tomato. GR, APX, reduced glutathione (GSH), oxidized glutathione (GSSG) and ascorbic acid (ASA) are the important components of ascorbate-glutathione pathway which is actively involved in scavenging of ROS (Mittler, 2002). Ascorbate-glutathione cycle involves a series of redox reactions where the net electron flow is from NADPH to $\mathrm{H}_{2} \mathrm{O}_{2}$ resulting in the conversion of $\mathrm{H}_{2} \mathrm{O}_{2}$ into water. Increased activity of GR helps in enhanced production of reduced glutathione. Reduced glutathione produced from the reduction of oxidised glutathione acts

Table 5. Mean of indole acetic acid, gibberellic acid, and abscisic acid in leaf of mycorrhizal and non-mycorrhizal tobacco plants exposed to varying concentrations of chloride (average of two growing seasons, 2012-2013).

\begin{tabular}{|c|c|c|c|}
\hline Treatment & $\begin{array}{c}\text { IAA } \\
\left(\mathrm{n} \mathrm{Mg} \text { fresh } \mathrm{wt}^{-1} \text { ) }\right.\end{array}$ & $\frac{\text { GA }}{\left(n \mathrm{Mg} \text { fresh } \mathrm{wt}^{-1} \text { ) }\right.}$ & $\begin{array}{c}\text { ABA } \\
\left(\mathrm{n} \mathrm{Mg} \text { fresh } w t^{-1}\right)\end{array}$ \\
\hline \multicolumn{4}{|l|}{$\mathrm{AM}+$} \\
\hline $\mathrm{Cl}$ & $474.36^{\mathrm{a}}$ & $215.33^{\mathrm{a}}$ & $71.33^{\mathrm{c}}$ \\
\hline $\mathrm{C} 2$ & $350.96^{\mathrm{b}}$ & $160.98^{b}$ & $110.45^{b c}$ \\
\hline $\mathrm{C} 3$ & $332.39^{\mathrm{b}}$ & $120.83^{c}$ & $145.10^{\mathrm{b}}$ \\
\hline C4 & $277.96^{\mathrm{c}}$ & $63.33^{\mathrm{d}}$ & $209.80^{\mathrm{a}}$ \\
\hline LSD & 40 & 21 & 29 \\
\hline \multicolumn{4}{|l|}{ AM- } \\
\hline $\mathrm{Cl}$ & $433.26^{\mathrm{a}}$ & $131.66^{\mathrm{a}}$ & $110.40^{\mathrm{d}}$ \\
\hline $\mathrm{C} 2$ & $300.12^{\mathrm{b}}$ & $98.10^{\mathrm{ab}}$ & $175.49^{c}$ \\
\hline $\mathrm{C} 3$ & $290.03^{b}$ & $73.96^{\mathrm{b}}$ & $250.23^{\mathrm{b}}$ \\
\hline $\mathrm{C} 4$ & $128.26^{\mathrm{c}}$ & $14.13^{c}$ & $376.45^{\mathrm{a}}$ \\
\hline LSD & 55 & 30 & 38 \\
\hline \multicolumn{4}{|l|}{ ANOVA } \\
\hline $\mathrm{C}$ & $*$ & $*$ & * \\
\hline AM & * & $*$ & $*$ \\
\hline $\mathrm{C} \times \mathrm{AM}$ & $*$ & $*$ & $*$ \\
\hline
\end{tabular}

IAA, indole acetic acid; GA, gibberellic acid; $\mathrm{ABA}$, abscisic acid; $\mathrm{AM}+$, mycorrhizal; $\mathrm{Cl}, 10 \mathrm{mg} \mathrm{Cl} \mathrm{L}^{-1}$; $\mathrm{C} 2,40$ mg Cl L-1; C3, 70 mg Cl L-1; C4, $100 \mathrm{mg} \mathrm{Cl} \mathrm{L}^{-1}$; LSD, least significance difference; AM-, non-mycorrhizal; ANOVA, analysis of variance; $C$, chloride; AM, arbuscular mycorrhizal. ${ }^{*} \mathrm{P} \leq 0.05$. ${ }^{\mathrm{a}-\mathrm{d}}$ Means with different letters are significantly different at $\mathrm{P} \leq 0.05$. as electro donor during the conversion of dehydroascorbate (DHA) into ASA and ASA acts a electron donor in conversion of $\mathrm{H}_{2} \mathrm{O}_{2}$ into water and oxygen (Mittler, 2002). Decrease in content of ASA and increase in GSH found in our study is in concurrence with the findings of Abd_Allh et al. (2015) for Sesbania sesban.

\section{Endogenous phytohormone}

Drastic decline was observed in endogenous levels of IAA and GA3 due to chloride stress (Table 5). Inoculation of AMF not only increased the growth hormone levels but also ameliorated the chloride induced deleterious effects (Table 5). However ABA levels decreased due to AMF inoculation while increased under chloride stress conditions (Table 5).

Chloride stressed tobacco plants showed drastic decline in the endogenous synthesis of IAA, and GA3 while as AMF inoculated plants showed higher contents of these growth regulators. Endophytic fungi cause increase in endogenous levels of IAA and GA (Abd_Allah et al., 2015). ABA plays an important role in plant responses to abiotic stresses including salinity. As expected, we found out that ABA levels in non-colonised and AM plants increased as a consequence of salinity. Previous studies showed that AM symbiosis can alter the levels of ABA in the host plant and that, under salinity stress, the levels of ABA are lower in AMcolonised than in non-colonised plants (Aroca et al., 2013), as we found here under non-saline conditions. These results, together with those of other physiological parameters, support that AM symbiosis improves plant fitness. Babu et al. (2012) demonstrated that salinity stressed tomato plants showed increment in the concentration of ABA and IAA leading to better adaptation of tomato to salt stress. Hamayun et al. (2010) observed that soybean cultivars subjected to salt stress exhibited increase in ABA and decrease in GA3 synthesis.

\section{Conclusions}

It is shown here that AM symbiosis alleviates the negative effects of salt stress in tobacco plants by altering the hormonal productions and affecting plant physiology in the host plant, allowing plants to grow better under these unfavourable conditions. The results confirm the potential of arbuscular mycorrhizas in protecting host plants against unfavourable environmental conditions and pave the way for applying AM symbiosis in sustainable agriculture in Mediterranean conditions. Due to the variability of plant response to mycorrhizal treatments requires, however, additional multi-year studies on a wider range of tobacco genotypes are needed. A further indication emerging from this study is that, under the climatic conditions of Northern Iran, the optimum chloride level in irrigation water for acceptable Virginia tobacco is below $25 \mathrm{mg} \mathrm{L}^{-1}$, whereas the level up to $40 \mathrm{mg} \mathrm{L}^{-1}$ in combination with AMF can be considered as the upper threshold limit.

\section{References}

Abd Allah EF, Hashem A, Alqarawi AA, Bahkali AH, Alwhibi MS, 2015. Enhancing growth performance and systemic acquired resistance of medicinal plant Sesbania sesban (L.) Merr using arbuscular mycorrhizal fungi under salt stress. Saudi J. Biol. Sci. 22:274-83.

Abeer H, Abd_Allah EF, Alqarawi AA, Egamberdieva D, 2015. 
Induction of salt stress tolerance in cowpea [Vigna unguiculata (L.) Walp.] by arbuscular mycorrhizal fungi. Legume Res. 38:579-88.

Anderson ME, 1985. Determination of glutathione and glutathione disulfide in biological samples. Methods Enzymol. 113:54855.

AOAC, 1997. Official methods of analysis of the Association of Official Analytical Chemists, 14th ed. AOAC, Arlington, VA, USA.

Aroca R, Ruiz-Lozano JM, Zamarreno AM, Paza JA, Garcia-Mina JM, Pozoa MJ, Lopez-Raez JA, 2013. Arbuscular mycorrhizal symbiosis influences strigolactone production under salinity and alleviates salt stress in lettuce plants. J. Plant Physiol. 170:47-55.

Babu MA, Singh D, Gothandam KM, 2012. The effect of salinity on growth, hormones and mineral elements in leaf and fruit of tomato cultivar PKM1. J. Anim. Plant Sci. 22:159-64.

Bates LS, Waldren RP, Teare LD, 1973. Rapid determination of free proline for water-stress studies. Plant Soil 39:205-7.

Bilgili U, Çarpici EB, Asik BB, Çelik N, 2011. Root and shoot response of common vetch (Vicia sativa L.), forage pea (Pisum sativum L.) and canola (Brassica napus L.) to salt stress during early seedling growth stages. Turkish J. Field Crops. 16:33-8.

Boyer JS, 1995. Why measure water status? In: J.S. Boyer (ed.) Measuring the water status of plants and soils. Academic Press, London, UK, pp. 1-12.

Bremmer JM, Mulvaney CS, 1982. Nitrogen-total. In: A.L. Page, R.H. Miller, and D.R. Keeney (eds.) Methods of soil analysis. Part 2. Chemical and microbiological properties. 2nd ed. American Society of Agronomy, Madison, WI, USA. pp. 595624.

Candido V, Campanelli G, D'Addabbo T, Castronuovo D, Perniola M, Camele I, 2015. Growth and yield promoting effect of artificial mycorrhization on field tomato at different irrigation regimes. Sci. Hortic. 187:35-43.

Candido V, Campanelli G, D’Addabbo T, Castronuovo D, Renco M, Camele I, 2013. Growth and yield promoting effect of artificial mycorrhization combined with different fertiliser rates on field-grown tomato. Ital. J. Agron. 8:e22.

Carlberg I, Mannervik B, 1985. Glutathione reductase. Methods Enzymol. 113:484-90.

Colella T, Candido V, Campanelli G, Camele I, Battaglia D, 2014. Effect of irrigation regimes and artificial mycorrhization on insect pest infestations and yield in tomato crop. Phytoparasitica 42:235-46.

Collins WK, Hawks Jr SN, 1993. Principles of flue-cured tobacco production. North Carolina State University, Raleigh, NC, USA.

CORESTA, 1994a. CORESTA recommended method No 35. Determination of total alkaloids (as nicotine) in tobacco by continuous flow analysis. Available from: https://www.coresta.org/sites/default/files/technical_documents/main/CRM_35update(Aug10).pdf

CORESTA, 1994b. CORESTA recommended method No 38. Determination of reducing carbohydrates in tobacco by continuous flow analysis. Available from: https:/www.coresta. org/sites/default/files/technical_documents/main/CRM_38update(Aug10).pdf

Cosme M, Wurst S, 2013. Interactions between arbuscular mycorrhizal fungi, rhizobacteria, soil phosphorus and plant cytokinin deficiency change the root morphology, yield and quality of tobacco. Soil Biol. Biochem. 57:436-43.

Daei G, Ardekani M, Rejali F, Teimuri S, Miransari M, 2009.
Alleviation of salinity stress on wheat yield, yield components, and nutrient uptake using arbuscular mycorrhizal fungi under field conditions. J. Plant Physiol. 166:217-25.

Datta P, Kulkarni M, 2014. Arbuscular mycorrhizal colonization improves growth and biochemical profile in Acacia arabica under salt stress. J. BioSci. Biotech. 3:235-45.

Dionisio-Sese ML, Tobita S, 1998. Antioxidant responses of rice seedlings to salinity stress. Plant Sci 135:1-9.

Fritz C, Palacios-Rojas N, Feil R, Stitt M, 2006. Regulation of secondary metabolism by the carbonenitrogen status in tobacco: nitrate inhibits large sectors of phenylpropanoid metabolism. Plant J. 46:533-48.

Gamalero E, Berta G, Massa N, Glick BR, Lingua G, 2010. Interactions between Pseudomonas putida UW4 and Gigaspora rosea BEG9 and their consequences for the growth of cucumber under salt-stress conditions. J. Appl. Microbiol. 108:236-45.

Gerdemann JW, 1975. Vesicular arbuscular mycorrhizal. In: D.G. Torrey, D.T.C. Clarkson (eds.). The development and function of roots. Academic Press, London, UK. pp. 575-91.

Giovannetti M, Mosse B, 1980. Estimating the percentage of root length colonized (Gridline-Intersect Method). New Phytol. 84:489-500.

Hamayun M, Khan SA, Khan AL, Shinwari ZK, Hussain J, Sohn EY, Kang SM, Kim, YH, Khan MA, Lee IJ, 2010. Effect of salt stress on growth attributes and endogenous growth hormones of Soybean cultivar Hwangkeumkong. Pak. J. Bot. 42:310312.

He Z, He C, Zhang Z, Zou Z, Wang H, 2007. Changes of antioxidative enzymes and cell membrane osmosis in tomato colonized by arbuscular mycorrhizae under $\mathrm{NaCl}$ stress. Colloid Surface B. 59, 128-133.

Karaivazoglou NA, Papakosta DK, Divanidis S, 2005. Effect of chloride in irrigation water and form of nitrogen fertilizer on Virginia (flue-cured) tobacco. Field Crops Res. 92:61-74.

Karaivazoglou NA, Papakosta DK, Divanidis S, 2006. Effect of chloride in irrigation water on oriental (sun-cured) tobacco. J. Plant Nutr. 29: 1413-1431.

Kumar A, Sharma S, Mishra S, 2010. Influence of arbuscular mycorrhizal (AM) fungi and salinity on seedling growth, solute accumulation and mycorrhizal dependency of Jatropha curcas L. J. Plant Growth Regul. 29:297-306.

Kumar A, Sharma S, Mishra S, Dames, JF, 2015. Arbuscular mycorrhizal inoculation improves growth and antioxidative response of Jatropha curcas (L.) under $\mathrm{Na}_{2} \mathrm{SO}_{4}$ salt stress. Plant Biosyst. 149:260-9.

Kusaba S, Kano-Murakami Y, Matsuoka M, Tamaoki M, Sakamoto T, Yamaguchi I, Fukumoto M, 1998. Alteration of hormone levels in transgenic tobacco plants over expressing a rice homeobox gene OSH1. Plant Physiol. 116:471-6.

Latef AAHA, Chaoxing H, 2011. Effect of arbuscular mycorrhizal fungi on growth, mineral nutrition, antioxidant enzymes activity and fruit yield of tomato grown under salinity stress. Sci. Hortic. 127:228-33.

Law MY, Charles SA, Halliwell B, 1983. Glutathione and ascorbic acid in spinach (Spinacia oleracea) chloroplasts: the effect of hydrogen peroxide and of Paraquat. Biochem. J. 210:899-903.

Lee IJ, Foster KR, Morgan PW, 1998. Photoperiod control of gibberellin levels and flowering in sorghum. Plant Physiol. 116:1003-10.

Luck H, 1974. Catalases. In: H.U. Bregmeyer (ed.). Methods of enzymatic analysis. Academic Press, New York, NY, USA.

Martinez-Ballesta MC, Martinez V, Carvajal M, 2004. Osmotic 
adjustment, water relations and gas exchange in pepper plants grown under $\mathrm{NaCl}$ or $\mathrm{KCl}$. Environ. Exp. Bot. 52:161-74.

Miransari M, 2010. Contribution of arbuscular mycorrhizal symbiosis to plant growth under different types of soil stress. Plant Biol. 12:563-9.

Mittler R, 2002. Oxidative stress, antioxidants and stress tolerance. Trends Plant Sci. 7:405-10.

Moran R, 1982. Formula for determination of chlorophyllous pigments extracted with N.N. dimethylformamide. Plant Physiol. 69:1371-81.

Nakano Y, Asada K, 1981. Hydrogen peroxide is scavenged by ascorbate-specific peroxidase in spinach chloroplast. Plant Cell Physiol. 22:867-80.

Olsen SR, Sommers LE, 1982. Phosphorus. In: A.L. Page, R.H. Miller, and D.R. Keeney (eds.). Methods of soil analysis. Part 2. Chemical and microbiological properties. 2nd ed. American Society of Agronomy, Madison, WI, USA. pp. 403-30.

Philips J, Hayman DS, 1970. Improved procedure for cleaning roots andstaining parasitic and vesicular-arbuscular mycorrhizal fungi for rapid assessment of infection. Trans. Brit. Mycol. Soc. 55:158-61.

Ruiz-Lozano JM, 2003. Arbuscular mycorrhizal symbiosis and alleviation of osmotic stress. New perspectives for molecular studies. Mycorrhiza 13:309-17.

Schußler A, Walker C, 2010. The Glomeromycota: a species list with new families and genera. The Royal Botanic Garden, Edinburgh \& Kew, UK.

Selvakumar G, Kim K, Hu S, Sa T, 2014. Effect of salinity on plants and the role of arbuscular mycorrhizal fungi and plant growth-promoting rhizobacteria in alleviation of salt stress. In: P. Ahmad, M.R. Wani (eds.). Physiological mechanisms and adaptation strategies in plants under changing environment. Vol. 1. Springer, New York, NY, USA. pp. 116-37.

Sifola MI, Postiglione L, 2002. The effect of increasing $\mathrm{NaCl}$ in irrigation water on growth, gas exchange and yield of tobacco Burley type. Field Crops Res. 74:81-91.

Smith SE, Read DJ, 1997. Mycorrhizal symbiose. Academic Press, London, UK.

Turner NC, 1981. Techniques and experimental approaches for the measurement of plant water status. Plant Soil 58:339-66.

Van Rossum MWPC, Alberda M, van der Plas LHW, 1997. Role of oxidative damage in tulip bulb scale micropropagation. Plant Sci. 130:207-16.

Wu QS, Zou YN, Abd_Allah EF, 2014. Mycorrhizal Association and ROS in Plants. In: P. Ahmad (ed.). Oxidative damage to plants. Elsevier, Amsterdam, The Netherlands. pp. 453-75.

Zhu XC, Song FB, Liu SQ, Liu TD, 2011. Effects of arbuscular mycorrhizal fungus on photosynthesis and water status of maize under high temperature stress. Plant Soil 346:189-99. 